\title{
KETERKAITAN EKSTRAK TELUR KEONG MAS DENGAN TINGKAT KETAHANAN SALINITAS BENIH KEDELAI (Glycine max (L.) Merrill)
}

\author{
Syukri dan Risky Ridha*) \\ Program Studi Agroteknologi, Fakultas Pertanian, Universitas Samudra, Kota Langsa 24415 \\ *e-mail: riskyridha@unsam.ac.id
}

\begin{abstract}
ABSTRAK
Wilayah pesisir mempunyai potensi cukup besar untuk dikembangkan menjadi lahan pertanian, namun peningkatan muka air laut akan menyebabkan terjadinya salinitas. Salah satu penyebab kerusakan tanaman pada kondisi salinitas adalah terjadinya cekaman oksidatif yang disebabkan oleh terakumulasinya senyawa Reactive Oxygen Species (ROS). Radikal ini dapat menyebabkan degradasi membran sel yang dapat menyebabkan hilangnya energi untuk biosintesis, cadangan makanan di embrio menjadi habis dan menurunnya viabilitas dan vigoritas benih. Penelitian ini bertujuan untuk mengkaji seberapa besar pengaruh dari ekstrak telur keong mas sebagai antioksidan alami dalam meningkatkan vigoritas benih kedelai (Glycine max (L.) Merril) pada kondisi cekaman salinitas. Penelitian disusun menggunakan Rancangan Acak Lengkap (RAL) faktorial dengan tiga ulangan. Sebagai faktor pertama yaitu kosentrasi ekstrak telur keong mas yang terdiri dari : E1 $(45 \%)$ dan E2 $(0 \%)$. faktor kedua yaitu kosentrasi larutan $\mathrm{NaCl}$ yang terdiri dari : $\mathrm{N} 0(\mathrm{NaCl} 0,0 \%), \mathrm{N} 1(\mathrm{NaCl} 0,5 \%), \mathrm{N} 2(\mathrm{NaCl} 1,0 \%)$ dan $\mathrm{N} 3(\mathrm{NaCl}$ $1,5 \%)$. Hasil penelitian menunjukkan bahwa pemberian ekstrak telur keong mas kosentrasi $45 \%$ hanya dapat meningkatkan daya berkecambah sebesar 51,59\%, kecepatan tumbuh sebesar 24,18 \%/etmal dan vigor kecambah sebesar 33,55 \% pada kondisi cekaman salinitas hingga $0,5 \%$, namun pada cekaman salinitas $1,0 \%$ dan $1,5 \%$ benih sudah tidak mampu untuk berkecambah normal. Peningkatan cekaman salinitas $0 \%-1,0 \%$ menyebabkan pengurangan panjang hipokotil dan panjang akar primer benih kedelai. Pemberian ekstrak telur keong mas kosentrasi $45 \%$ menghasilkan hipokotil dan akar primer benih kedelai yang lebih panjang dibandingkan dengan tanpa pemberian ekstrak. Hasil penelitian membuktikan adanya perbaikan viabilitas dan vigoritas benih yang ditunjukkan oleh indikasi fisiologi yaitu perbaikan performansi panjang hipokotil dan akar primer, meningkatkan nilai kecepatan tumbuh dan vigor kecambah benih kedelai dengan perendaman ekstrak telur keong mas pada kondisi salinitas walaupun pada level yang rendah.
\end{abstract}

Kata kunci : Benih Kedelai, Ekstrak telur keong mas dan Salinitas.

\section{PENDAHULUAN}

Kebutuhan kedelai di Indonesia terus-menerus meningkat seiring dengan pertambahan penduduk. Salah satu upaya untuk meningkatkan produksi kedelai adalah melalui perluasan areal penanaman. Akan tetapi perluasan penanaman kedelai mengalami kendala, di mana tanah-tanah produktif banyak digunakan untuk areal industri dan perumahan, di sisi lain masih banyaknya tanah yang belum dimanfaatkan. Tanah salin terutama di wilayah pesisir adalah salah satu lahan yang belum dimanfaatkan secara luas untuk kegiatan budidaya tanaman.

Wilayah pesisir mempunyai potensi cukup besar untuk dikembangkan menjadi lahan pertanian. Namun terjadinya peningkatan muka air laut memberikan 
pengaruh yang sangat besar (WieczorekZeul, 2008). Peningkatan muka air laut akan menyebabkan terjadinya peningkatan salinitas yang kemudian berpengaruh terhadap sistem pola tanam di daerah tersebut (Grattan, 2005).

Cekaman salinitas mepengaruhi perkecambahan dengan mencegah penyerapan air dan juga masukkan ion beracun ke dalam embrio atau bibit. Tingkat toleransi tanaman terhadap cekaman garam jauh lebih besar selama perkecambahan biji dari pada selama fase berikutnya, seperti pertumbuhan bibit dan perkembangan tanaman (Suwarno dan Solahuddin, 1983). Pengaruh $\mathrm{NaCl}$ pada proses perkecambahan antara lain mengurangi hidrasi dari embrio dan kotiledon, menghambat dan mengurangi pemunculan radikula dan plumula, dan mengurangi pertumbuhan kecambah serta menyebabkan beberapa kelainan pada benih dan propagula selama perkecambahan (Wahid et al., 1999).

Pada kondisi salin, pertumbuhan dan perkembangan tanaman terhambat karena akumulasi berlebihan dari $\mathrm{Na}$ dan $\mathrm{Cl}$ dalam sitoplasma, menyebabkan perubahan metabolisme di dalam sel (Yuniati, 2004). Salah satu penyebab kerusakan tanaman pada kondisi kekeringan dan salinitas adalah terjadinya cekaman oksidatif yang disebabkan oleh terakumulasinya senyawa Reactive Oxygen Species (ROS) seperti superoksida $\left(\mathrm{O}_{2^{-}}\right)$, hidrogen peroksida $\left(\mathrm{H}_{2} \mathrm{O}_{2}\right)$ dan radikal hidroksil (OH) (Pritchard et al., 2000; Prochazkova et al., 2001). Radikal ini dapat menyebabkan degradasi membran sel yang dapat menyebabkan : (1) hilangnya kontrol permeabilitas membran sel, (2) hilangnya energi untuk proses biosintesis dan kecepatan respirasi bertambah, (3) cadangan makanan di embrio menjadi habis, dan (4) menurunnya viabilitas dan vigor benih (Addai dan Kantanka, 2006; Shiddiqui et al., 2008; Soltani et al., 2010).

Benih sangat rentan terhadap cekaman selama penanaman dan perkembangan awal, sehingga perlakuan untuk mempercepat periode perkecambahan mungkin dapat meningkatkan penampilan benih. Salah satu cara yang dapat dilakukan adalah dengan perendaman benih dalam larutan yang mengandung antioksidan. Penggunaan antioksidan alami nonenzimatik seperti karotenoid merupakan pendekatan yang efisien dan secara teknis lebih mudah untuk meminimalkan dampak buruk dari cekaman salinitas terhadap perkecambahan dan pertumbuhan tanaman.

Telur keong mas mengandung pigmen karotenoid alami yang cukup tinggi (Desiana 2000). Hasil penelitian Ameliawati, (2013) total karotenoid telur keong mas mencapai 313,48 \pm 19,73 ppm. Senyawa karotenoid merupakan kelompok pigmen dan antioksidan alami yang dapat meredam radikal bebas (Stahl dan Sies, 2003). Pertahanan juvenil terhadap penyakit dan stres oksidatif (Tyndale et al., 2008). Juga sebagai komponen penting pada pertumbuhan tanaman dan fotosintesis (Kurniawan et al. 2010).

Astaksantin merupakan karotenoid utama pada telur keong mas (Dreon et al. 2004). Astaxanthin merupakan pigmen karotenoid alami dan memiliki kekuatan antioksidan yang jauh lebih tinggi dibandingkan antioksidan lain yang sudah dikenal seperti vitamin $\mathrm{E}$ dan $\mathrm{C}$ (asam askorbat). Memiliki aktivitas menetralkan singlet oksigen dan peroksidasi lipid yang jauh lebih kuat (Kurashige et al., 1990). Penelitian ini bertujuan untuk mengkaji 
seberapa besar pengaruh dari ekstrak telur keong mas sebagai antioksidan alami dalam meningkatkan vigoritas benih kedelai (Glycine max (L.) Merril) pada kondisi salinitas.

\section{METODELOGI PENELITIAN}

\section{Tempat dan Waktu Penelitian}

Penelitian ini dilaksanakan di Laboratorium Agroteknologi Fakultas Pertanian, Universitas Samudra, Kota Langsa, Provinsi Aceh, yang dilaksanakan pada bulan Agustus sampai dengan bulan Oktober 2017.

\section{Bahan dan Alat}

Bahan yang digunakan dalam penelitian ini meliputi benih kedelai varietas Anjasmoro diperoleh dari UPBS Balitkabi Malang, telur keong mas (Pomacea canaliculata), Alkohol 90\%, media substrat kertas merang, kertas label, kantung plastik transparan dan aquadest. sedangkan alat yang digunakan meliputi timbangan digital (capasity $500 \mathrm{~g}$ ), alat pengepres kertas, alat pengecambah benih, hand spryer, pinset, gelas beaker $1000 \mathrm{ml}$, gelas ukur $50 \mathrm{ml}$, blender, wadah plastik, saringan dan alat lain yang mendukung penelitian ini.

\section{Metode Penelitian}

Penelitian ini disusun dengan menggunakan Rancangan Acak Lengkap (RAL) pola faktorial dengan tiga ulangan. Faktor pertama adalah kosentrasi ekstrak telur keong mas (E) yang terdiri dari 2 taraf yaitu E1 (45 \%) dan E2 (0\%) dan faktor kedua adalah kosentrasi larutan $\mathrm{NaCl}(\mathrm{N})$ yang terdiri dari 4 taraf yaitu $\mathrm{NO}(\mathrm{NaCl} 0,0$ $\%), \mathrm{N} 1(\mathrm{NaCl} 0,5 \%), \mathrm{N} 2(\mathrm{NaCl} 1,0 \%)$ dan $\mathrm{N} 3 \quad(\mathrm{NaCl} 1,5 \%)$. Untuk setiap satuan percobaan terdiri atas 25 butir benih. Data hasil pengamatan dianalisis dengan sidik ragam (uji F) pada taraf 0,05 dan 0,01.
Apabila pengaruh perlakuan berbeda nyata maka dilanjutkan dengan uji jarak berganda Duncan (DMRT) pada taraf 0,05.

\section{Pelaksanaan Penelitian}

Benih kedelai direndam dalam air selama 5 menit, benih yang tenggelam secara fisik dianggap bernas yang kemudian digunakan untuk percobaan. Pada persiapan media untuk pengujian salinitas, substrat kertas direndam dengan larutan $\mathrm{NaCl}$, kecuali perlakuan tanpa $\mathrm{NaCl}$ direndam dalam aquadest. Kosentrasi larutan $\mathrm{NaCl}$ yang digunakan masingmasing adalah $0,0 \%, 0,5 \%, 1,0 \%$ dan $1,5 \%$. Untuk mendapatkan kosentrasi tersebut $\mathrm{NaCl}$ dilarutkan dalam $1000 \mathrm{ml}$ aquadest. Kemudian substrat kertas dipres dengan menggunakan alat pengepres hingga kadar air kertas mencapai kapasitas lapang.

Benih yang telah dipilih selanjutnya direndam dalam ekstrak telur keong mas sesuai kosentrasi perlakuan, masingmasing selama 2 jam, lalu benih ditiriskan dan dikeringanginkan diatas tisu. Benih lalu dikecambahkan pada media substrat kertas yang telah direndam dengan larutan $\mathrm{NaCl}$ tersebut dengan metode Uji kertas digulung didirikan dalam plastik (UKDdp) dan diberi label sesuai kosentrasi perlakuan. Diamati hari ke-2 sampai ke-5 setelah tanam.

Parameter yang diamati meliputi daya berkecambah (\%), kecepatan tumbuh (\%/etmal), vigor kecambah (\%), panjang hipokotil dan panjang akar primer $(\mathrm{cm})$

\section{HASIL DAN PEMBAHASAN}

Rekapitulasi hasil analisis ragam pengaruh perlakuan ekstrak telur keong mas dan kosentrasi larutan $\mathrm{NaCl}$ terhadap daya berkecambah, kecepatan tumbuh, vigor kecambah, panjang hipokotil dan 
panjang akar primer benih kedelai disajikan pada Tabel 1.

\section{Daya Berkecambah}

Hasil sidik ragam menunjukkan bahwa perlakuan ekstrak telur keong mas dan kosentrasi larutan $\mathrm{NaCl}$ memberikan pengaruh yang sangat nyata terhadap daya berkecambah benih kedelai baik faktor tunggal maupun interaksi (Tabel 1).

Benih yang diberikan ekstrak telur keong mas $45 \%$ pada kosentrasi larutan
$\mathrm{NaCl}$ 0,5 \% (E1N1) menunjukkan daya berkecambah benih yang nyata lebih baik sebesar 51,59\% bila dibandingkan dengan tanpa pemberian ekstrak pada kosentrasi larutan $\mathrm{NaCl}$ 0,5 \% (E2N1) (Tabel 2). Dengan pemberian ekstrak telur keong mas terjadi peningkatan daya berkecambah benih sebesar $24,17 \%$ pada kondisi salinitas, namun hanya sampai kosentrasi larutan $\mathrm{NaCl} 0,5 \%$ sedangkan pada kosentrasi $1,0 \%$ dan 1,5\% benih sudah tidak mampu untuk berkecambah normal.

Tabel 1. Rekapitulasi analisis ragam pengaruh perlakuan ekstrak telur keong mas (E) dan kosentrasi larutan $\mathrm{NaCl}(\mathrm{N})$ terhadap daya berkecambah (DB), kecepatan tumbuh (KcT), vigor kecambah (VK), panjang hipokotil $(\mathrm{PH})$ dan panjang akar primer (PAP) benih kedelai (Glycine max (L.) Merrill)

\begin{tabular}{ccccccc}
\hline \multirow{2}{*}{$\begin{array}{c}\text { Sumber } \\
\text { keragaman }\end{array}$} & $\begin{array}{c}\text { derajat } \\
\text { bebas }\end{array}$ & DB $(\%)$ & $\begin{array}{c}\text { KcT } \\
(\% / \text { etmal })\end{array}$ & VK $(\%)$ & PH $(\mathrm{cm})$ & PAP $(\mathrm{cm})$ \\
\hline Perlakuan & 7 & - & - & - & - & - \\
E & 1 & $88,96^{* *}$ & $48,79^{* *}$ & $36,50^{* *}$ & $4,66^{*}$ & $5,39^{*}$ \\
N & 3 & $1857,26^{* *}$ & $1871,75^{* *}$ & $509,21^{* *}$ & $214,42^{* *}$ & $207,49^{* *}$ \\
E x N & 3 & $32,92^{* *}$ & $17,03^{* *}$ & $13,74^{* *}$ & $1,48^{\text {tn }}$ & $0,89^{\text {tn }}$ \\
Galat & 16 & - & - & - & - & - \\
\hline Total & 23 & - & - & - & - & - \\
\hline KK $(\%)$ & & 6,49 & 6,30 & 12,38 & 14,38 & 14,86 \\
\hline
\end{tabular}

Keterangan : *) nyata pada tingkat kepercayaan $95 \%$;*) Sangat nyata pada tingkat kepercayaan $99 \% ;{ }^{\mathrm{tn}}$ ) Tidak nyata.

Tabel 2. Rata-rata daya berkecambah benih kedelai akibat pemberian ekstrak telur keong mas pada berbagai kosentrasi larutan $\mathrm{NaCl}(\%)$

\begin{tabular}{lcc}
\hline \multirow{2}{*}{ Perlakuan } & \multicolumn{2}{c}{ Ekstrak telur keong mas $(\mathrm{E})$} \\
\cline { 2 - 3 } & $\mathrm{E} 1(45 \%)$ & $\mathrm{E} 2(0 \%)$ \\
\hline Kosentrasi $\mathrm{NaCl}(\mathrm{N})$ & $\ldots \ldots \ldots \ldots \ldots \ldots \ldots \ldots \ldots \ldots \ldots \ldots \ldots \ldots \ldots \ldots \ldots \ldots \ldots \ldots \ldots \ldots \ldots \ldots \ldots$ \\
$\mathrm{N} 0(0,0 \%)$ & $65,43 \mathrm{a}$ & $49,22 \mathrm{~b}$ \\
$\mathrm{~N} 1(0,5 \%)$ & $51,59 \mathrm{~b}$ & $41,55 \mathrm{c}$ \\
$\mathrm{N} 2(1,0 \%)$ & $0,57 \mathrm{~d}$ & $0,57 \mathrm{~d}$ \\
$\mathrm{~N} 3(1,5 \%)$ & $0,57 \mathrm{~d}$ & $0,57 \mathrm{~d}$ \\
\hline
\end{tabular}

Keterangan : Angka yang diikuti oleh huruf yang sama pada baris dan kolom yang sama menunjukkan tidak berbeda nyata berdasarkan uji Duncan taraf $5 \%$; Data daya berkecambah ditransformasi dengan Arcsin $\sqrt{ }(x+0,5)$. 


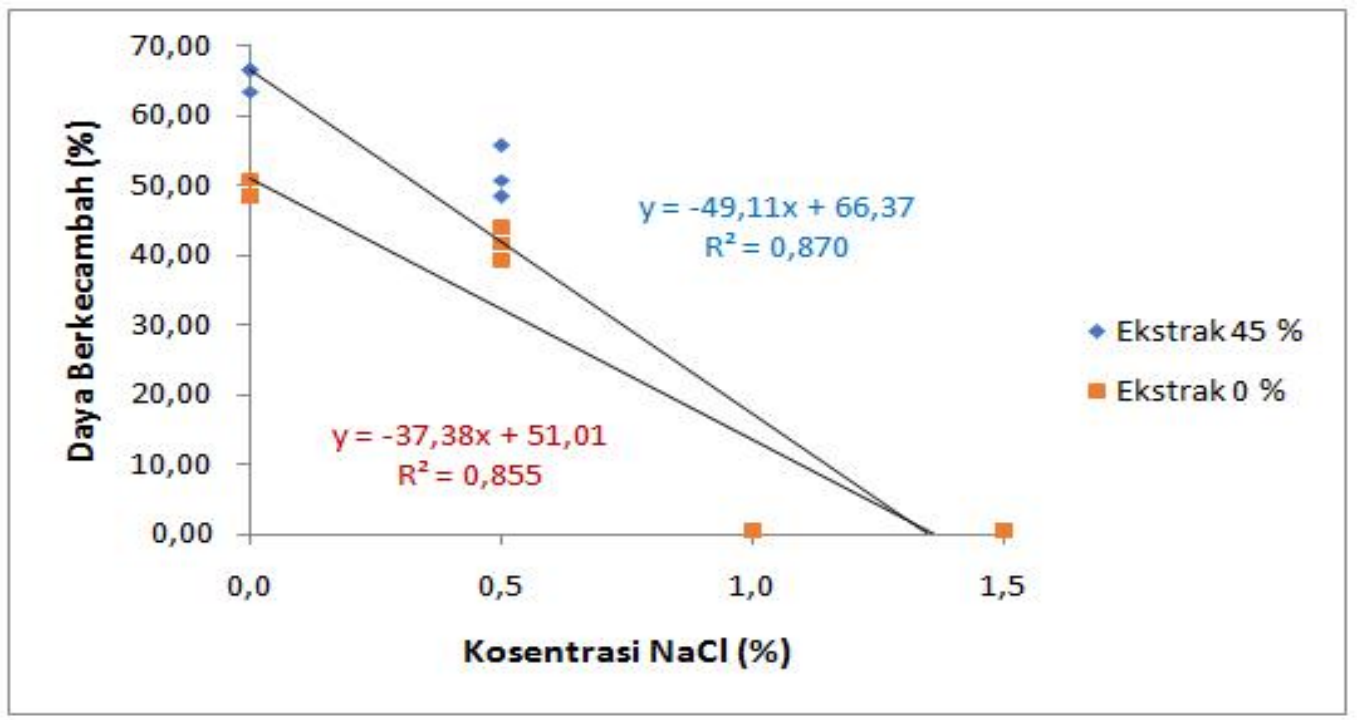

Gambar 1. Hubungan antara tingkat salinitas terhadap daya berkecambah (\%) benih kedelai pada dua perlakuan kosentrasi ekstrak telur keong mas.

Hubungan salinitas dengan daya berkecambah benih kedelai pada perlakuan perendaman ekstrak telur keong mas $45 \%$ dan $0 \%$ berbentuk linier negatif yaitu semakin tinggi kosentrasi $\mathrm{NaCl}$ (salinitas) maka semakin menurun daya berkecambah benih dengan persamaan regresi masingmasing yaitu $\mathrm{y}=-49,11 \mathrm{x}+66,37$ dengan koefisien determinasi $\mathrm{R}^{2}=0,870 ; \mathrm{y}=$ $-37,38 x+51,01\left(R^{2}=0,855\right)($ Gambar 1$)$.

\section{Kecepatan Tumbuh dan Vigor Kecambah}

Hasil sidik ragam menunjukkan bahwa perlakuan ekstrak telur keong mas dan kosentrasi larutan $\mathrm{NaCl}$ memberikan pengaruh yang sangat nyata terhadap kecepatan tumbuh dan vigor kecambah benih kedelai baik faktor tunggal maupun interaksi (Tabel 1).

Benih yang diberikan ekstrak telur keong mas $45 \%$ pada kosentrasi larutan $\mathrm{NaCl} \quad 0,5 \quad \% \quad$ (E1N1) menunjukkan kecepatan tumbuh benih yang nyata lebih tinggi sebesar 24,18 \%/etmal bila dibandingkan dengan tanpa pemberian ekstrak pada kosentrasi larutan $\mathrm{NaCl} \mathrm{0,5 \%}$ (E2N1) (Tabel 3). Dengan pemberian ekstrak telur keong mas terjadi peningkatan kecepatan tumbuh benih sebesar 18,83 \% pada kondisi salinitas, namun hanya sampai kosentrasi larutan $\mathrm{NaCl}$ 0,5\% sedangkan pada kosentrasi 1,0 $\%$ dan $1,5 \%$ benih sudah tidak mampu untuk berkecambah normal.

Kecepatan tumbuh (KcT) merupakan salah satu tolok ukur yang mengindikasikan vigor kekuatan tumbuh benih. Nilai KcT yang tinggi mencerminkan benih yang vigor, karena benih dapat berkecambah cepat pada waktu yang relatif singkat (Sadjad et al., 1999).

Hubungan salinitas dengan kecepatan tumbuh benih kedelai pada perlakuan perendaman ekstrak telur keong mas $45 \%$ dan $0 \%$ berbentuk linier negatif yaitu semakin tinggi kosentrasi $\mathrm{NaCl}$ (salinitas) maka semakin menurun kecepatan tumbuh benih dengan persamaan regresi masing-masing yaitu $\mathrm{y}=-22,11 \mathrm{x}+30,31$ dengan koefisien determinasi $\mathrm{R}^{2}=0,862 ; \mathrm{y}=-18,22 \mathrm{x}+$ $25,12\left(\mathrm{R}^{2}=0,859\right)($ Gambar 2).

Pada parameter vigor kecambah benih, pemberian ekstrak telur keong mas 
$45 \%$ pada kosentrasi larutan $\mathrm{NaCl} 0,5 \%$ (E1N1) menunjukkan hasil yang nyata lebih tinggi sebesar $33,55 \%$ bila dibandingkan dengan tanpa pemberian ekstrak pada kosentrasi larutan $\mathrm{NaCl} 0,5 \%$ (E2N1) (Tabel 4). Dengan pemberian ekstrak telur keong mas terjadi peningkatan vigor kecambah benih sebesar $31,22 \%$ pada kondisi salinitas, namun hanya sampai kosentrasi larutan $\mathrm{NaCl} 0,5$ $\%$ sedangkan pada kosentrasi $1,0 \%$ dan $1,5 \%$ benih sudah tidak mampu untuk berkecambah normal.

Tabel 3. Rata-rata kecepatan tumbuh benih kedelai akibat pemberian ekstrak telur keong mas pada berbagai kosentrasi larutan $\mathrm{NaCl}$ (\%/etmal)

\begin{tabular}{lrc}
\hline \multirow{2}{*}{ Perlakuan } & \multicolumn{2}{c}{ Ekstrak telur keong mas $(\mathrm{E})$} \\
\cline { 2 - 3 } & $\mathrm{E} 1(45 \%)$ & $\mathrm{E} 2(0 \%)$ \\
\hline Kosentrasi $\mathrm{NaCl}(\mathrm{N})$ & $\ldots \ldots \ldots \ldots \ldots \ldots . . . \% /$ etmal $\ldots \ldots \ldots \ldots \ldots \ldots$ \\
$\mathrm{N} 0(0,0 \%)$ & $29,56 \mathrm{a}$ & $24,35 \mathrm{~b}$ \\
$\mathrm{~N} 1(0,5 \%)$ & $24,18 \mathrm{~b}$ & $20,35 \mathrm{c}$ \\
$\mathrm{N} 2(1,0 \%)$ & $0,57 \mathrm{~d}$ & $0,57 \mathrm{~d}$ \\
$\mathrm{~N} 3(1,5 \%)$ & $0,57 \mathrm{~d}$ & $0,57 \mathrm{~d}$ \\
\hline
\end{tabular}

Keterangan : Angka yang diikuti oleh huruf yang sama pada baris dan kolom yang sama menunjukkan tidak berbeda nyata berdasarkan uji Duncan taraf $5 \%$; Data kecepatan tumbuh ditransformasi dengan $\operatorname{Arcsin} \sqrt{(x+0,5)}$.

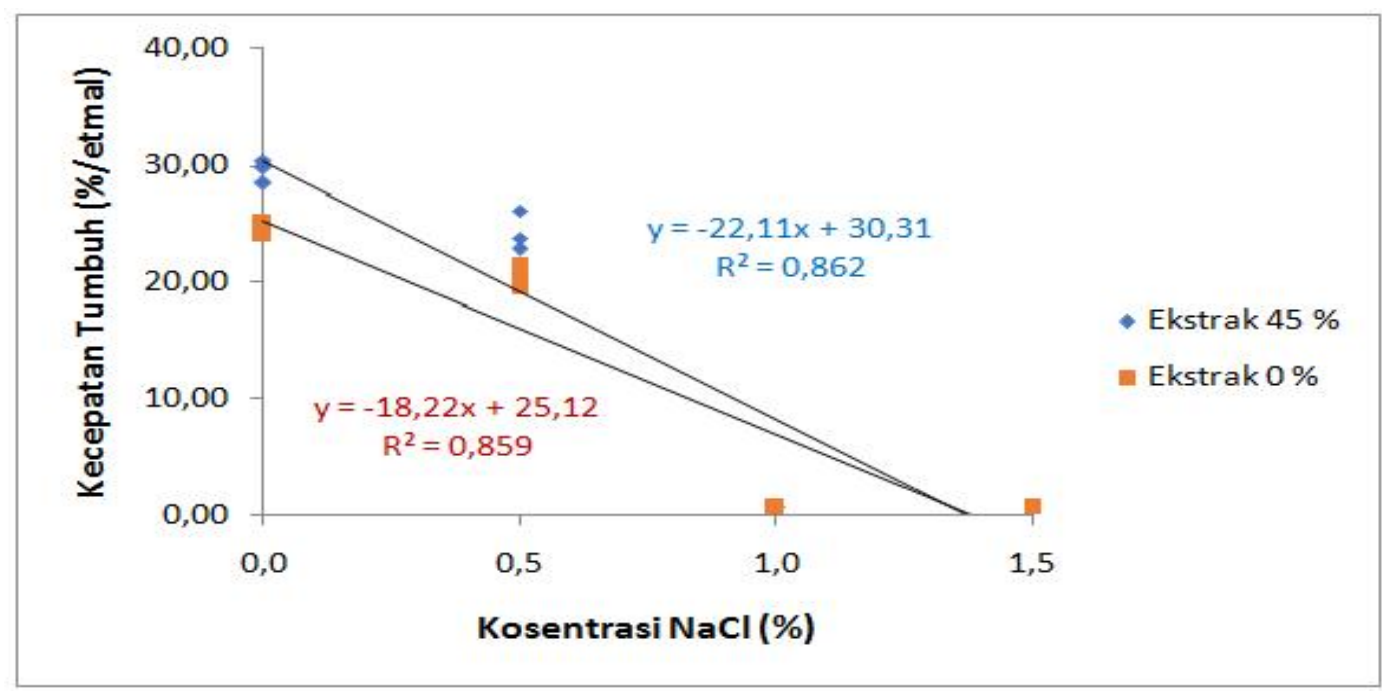

Gambar 2. Hubungan antara tingkat salinitas terhadap kecepatan tumbuh (\%/etmal) benih kedelai pada dua perlakuan kosentrasi ekstrak telur keong mas.

Kondisi ini menunjukkan bahwa ekstrak telur keong mas yang diberikan diduga dapat menekan stres oksidatif yang dialami benih akibat salinitas, namun sampai kosentrasi larutan $\mathrm{NaCl} 0,5 \%$ walaupun hanya dapat mempertahankan vigor kecambah pada level yang rendah. Telur keong mas mengandung pigmen karotenoid alami yang cukup tinggi.
Senyawa karotenoid merupakan kelompok pigmen dan antioksidan alami yang dapat meredam radikal bebas (Stahl dan Sies, 2003).

Hasil penelitian Ameliawati (2013), total karotenoid telur keong mas mencapai $313,48 \pm 19,73$ ppm. Astaksantin merupakan karotenoid utama pada telur keong mas. Astaksantin merupakan 
antioksidan yang sangat kuat. Kapasitas antioksidan karotenoid ovorubin telur keong mas telah dipelajari dengan inhibisi oksidasi mikrosomal dalam sistem non enzimatik yang menunjukkan proteksi kuat terhadap kerusakan oksidatif (Dreon et al., 2004), pertahanan juvenil terhadap penyakit dan stres oksidatif (Tyndale et al., 2008).
Hubungan salinitas dengan vigor kecambah benih kedelai pada perlakuan perendaman ekstrak telur keong mas $45 \%$ dan $0 \%$ juga berbentuk linier negatif yaitu semakin tinggi kosentrasi $\mathrm{NaCl}$ (salinitas) maka semakin menurun vigor benihnya dengan persamaan regresi masing-masing yaitu $y=-33,94 x+45,66$ dengan koefisien determinasi $\mathrm{R}^{2}=0,880 ; \mathrm{y}=-24,28 \mathrm{x}+$ $33,07\left(\mathrm{R}^{2}=0,863\right)($ Gambar 3).

Tabel 4. Rata-rata vigor kecambah benih kedelai akibat pemberian ekstrak telur keong mas pada berbagai kosentrasi larutan $\mathrm{NaCl}(\%)$

\begin{tabular}{|c|c|c|}
\hline \multirow{2}{*}{ Perlakuan } & \multicolumn{2}{|c|}{ Ekstrak telur keong mas (E) } \\
\hline & E1 $(45 \%)$ & $\bar{E} 2(0 \%)$ \\
\hline Kosentrasi $\mathrm{NaCl}(\mathrm{N})$ & \multicolumn{2}{|c|}{ …............... \% …............... } \\
\hline N0 $(0,0 \%)$ & $46,15 \mathrm{a}$ & $32,72 \mathrm{~b}$ \\
\hline $\mathrm{N} 1(0,5 \%)$ & $33,55 \mathrm{~b}$ & $25,57 \mathrm{c}$ \\
\hline $\mathrm{N} 2(1,0 \%)$ & $0,57 \mathrm{~d}$ & $0,57 \mathrm{~d}$ \\
\hline $\mathrm{N} 3(1,5 \%)$ & $0,57 \mathrm{~d}$ & $0,57 \mathrm{~d}$ \\
\hline
\end{tabular}

Keterangan : Angka yang diikuti oleh huruf yang sama pada baris dan kolom yang sama menunjukkan tidak berbeda nyata berdasarkan uji Duncan taraf $5 \%$; Data vigor kecambah ditransformasi dengan Arcsin $\sqrt{ }(x+0,5)$.

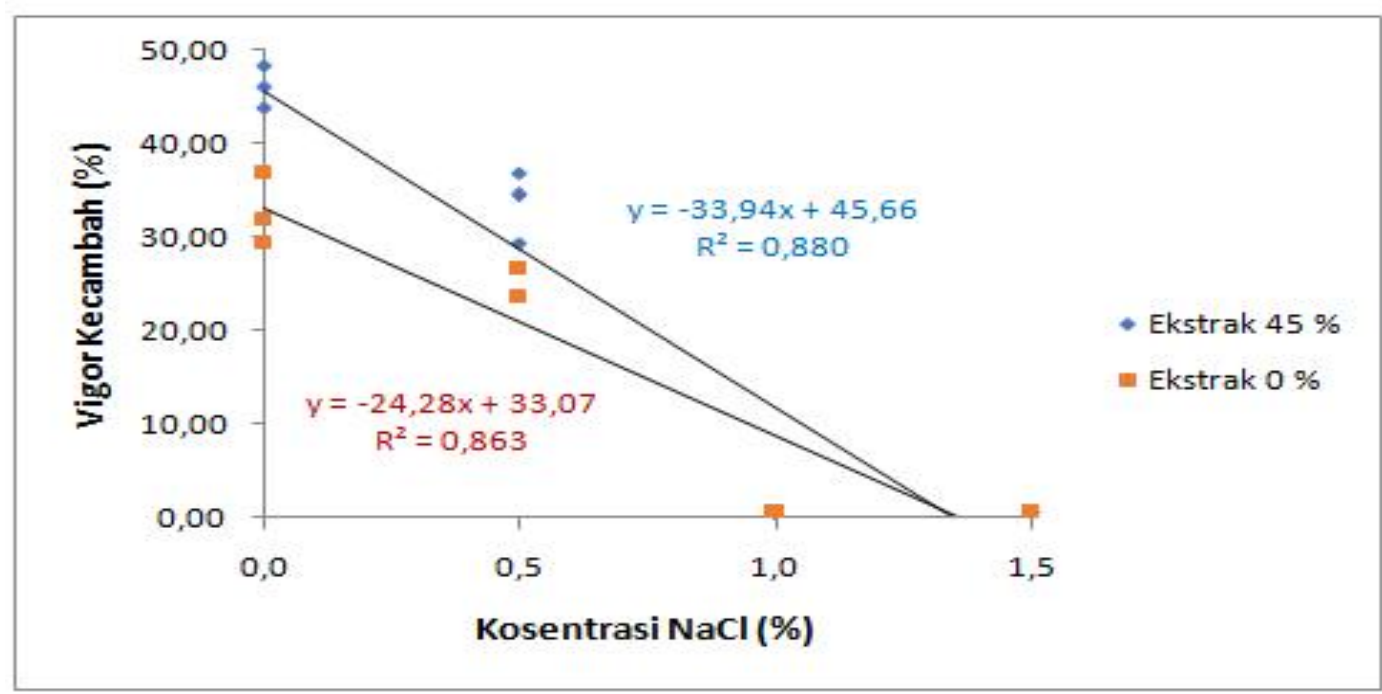

Gambar 3. Hubungan antara tingkat salinitas terhadap vigor kecambah (\%) benih kedelai pada dua perlakuan kosentrasi ekstrak telur keong mas.

Astaxanthin merupakan pigmen dikenal seperti vitamin $\mathrm{E}$ dan $\mathrm{C}$ (asam karotenoid alami dan memiliki kekuatan askorbat). Memiliki aktivitas menetralkan antioksidan yang jauh lebih tinggi singlet oksigen dan peroksidasi lipid yang dibandingkan antioksidan lain yang sudah jauh lebih kuat (Kurashige et al., 1990). 


\section{Panjang Hipokotil dan Akar Primer}

Hasil sidik ragam menunjukkan bahwa panjang hipokotil dan panjang akar primer benih kedelai pada perlakuan ekstrak telur keong mas memberikan pengaruh yang nyata, perlakuan larutan $\mathrm{NaCl}$ memberikan pengaruh yang sangat nyata, sedangkan interaksi dari kedua faktor tersebut tidak memberikan pengaruh yang nyata (Tabel 1).

Perlakuan ekstrak telur keong mas dengan kosentrasi $45 \%$ (E1) nyata meningkatkan panjang hipokotil mencapai 9,64 $\mathrm{cm}$ dan panjang akar primer mencapai $12,82 \mathrm{~cm}$, bila dibandingkan dengan tanpa pemberian ekstrak (E2) panjang hipokotil hanya sebesar $8,42 \mathrm{~cm}$ dan panjang akar primer hanya sebesar $11,03 \mathrm{~cm}$. Dengan kata lain, terjadi peningkatan panjang hipokotil sebesar 14,53\% dan panjang akar primer sebesar 16,25 \% akibat pemberian ekstrak telur keong mas (Gambar 4 dan 5).

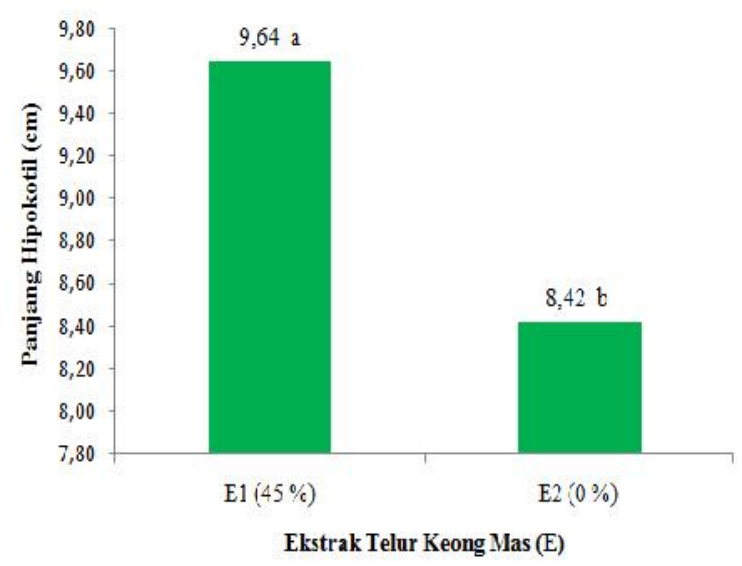

Gambar 4. Panjang hipokotil benih kedelai akibat perlakuan konsentrasi ekstrak telur keong mas $(\mathrm{cm})$; Angka yang diikuti oleh huruf yang sama menunjukkan tidak berbeda nyata berdasarkan uji Duncan taraf $5 \%$; Data panjang hipokotil ditransformasi dengan Arcsin $\sqrt{ }(x+0,5)$.

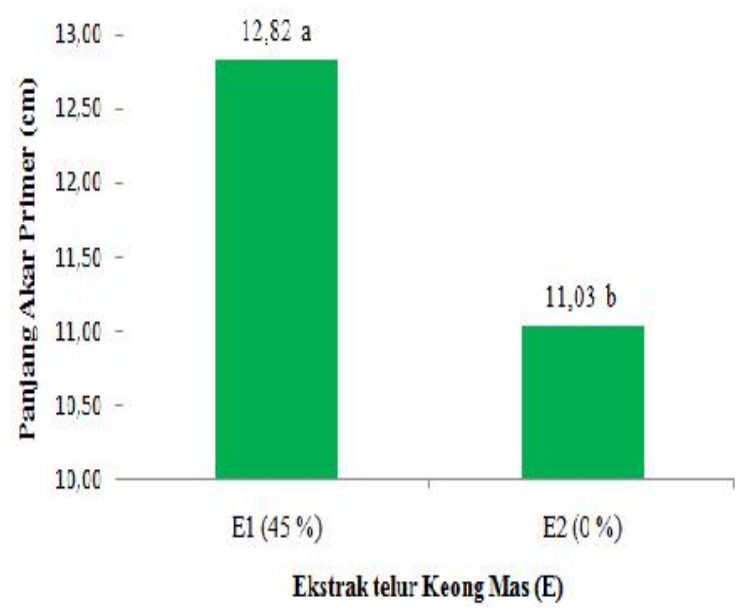

Gambar 5. Panjang akar primer benih kedelai akibat perlakuan konsentrasi ekstrak telur keong mas (cm); Angka yang diikuti oleh huruf yang sama menunjukkan tidak berbeda nyata berdasarkan uji Duncan taraf $5 \%$; Data panjang akar primer ditransformasi dengan $\operatorname{Arcsin} \sqrt{ }(x+0,5)$.

Meningkatnya panjang hipokotil dan panjang akar primer pada pemberian ekstrak telur keong mas kosentrasi $45 \%$ diduga disebabkan karna ekstrak telur keong mas mengandung mikroba Aspergillus niger yang dapat menghasilkan hormon tumbuh seperti auksin dan giberelin. Jamur Aspergillus niger mampu menghasilkan hormon IAA dari golongan Auksin (Subowo, 2010) dan menghasilkan giberelic acid $\left(\mathrm{GA}_{3}\right)$ (Bilkay et al., 2010). Selanjutnya hasil penelitian Sugiharto (2013) juga menunjukkan bahwa telur keong mas memiliki potensi IAA sebesar 0,457 ppm. Dengan adanya penambahan giberelin dan auksin eksternal dari ekstrak telur keong mas menyebabkan terjadinya peningkatan jumlah giberelin dan auksin di dalam benih, yang akan meningkatkan ketersediaan dan aktivitas enzim alfa amylase untuk merubah pati menjadi gula sebagai sumber makanan bagi 
perkembangan embrio dalam waktu yang cepat, sehingga akan mempengaruhi panjang hipokotil dan panjang akar primer benih kedelai.

Auksin dapat menaikkan tekanan osmotik, meningkatkan permeabilitas sel terhadap air, meningkatkan sintesis protein, meningkatkan plastisitas dan pengembangan sel (Abidin, 1985). Peningkatan tekanan osmotik akan menentukan banyaknya air yang masuk ke dalam benih. Adanya air dalam benih akan mengtriger segala proses fisiologi dalam sel sehingga mempercepat proses perkecambahan (Kamil, 1991). Sedangkan giberelin mempunyai peranan besar dalam perkecambahan dan perkembangan benih. Andreoli and Khan (1999) menyatakan bahwa giberelin memiliki peranan dalam perombakan cadangan makanan dan sebagai penginduksi enzim perombakan endosperm, sampai tersedianya energi untuk pertumbuhan embrio.

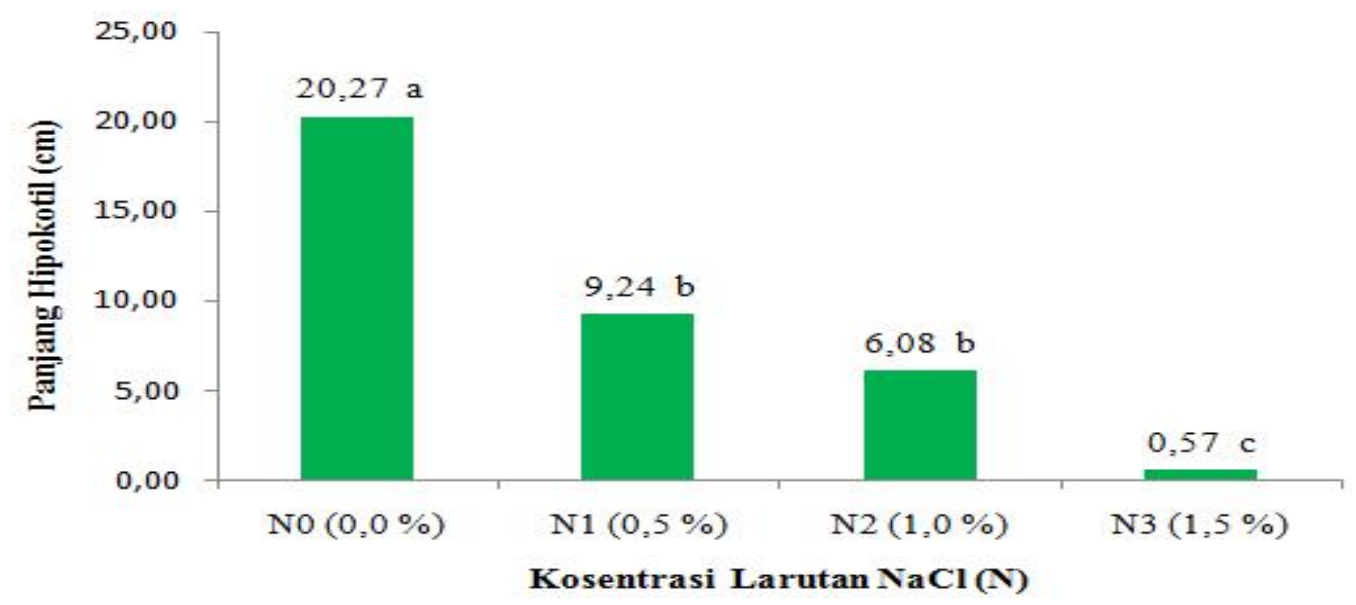

Gambar 6. Panjang hipokotil benih kedelai akibat perlakuan konsentrasi larutan $\mathrm{NaCl}$ $(\mathrm{cm})$; Angka yang diikuti oleh huruf yang sama menunjukkan tidak berbeda nyata berdasarkan uji Duncan taraf $5 \%$; Data panjang hipokotil ditransformasi dengan Arcsin $\sqrt{ }(x+0,5)$.

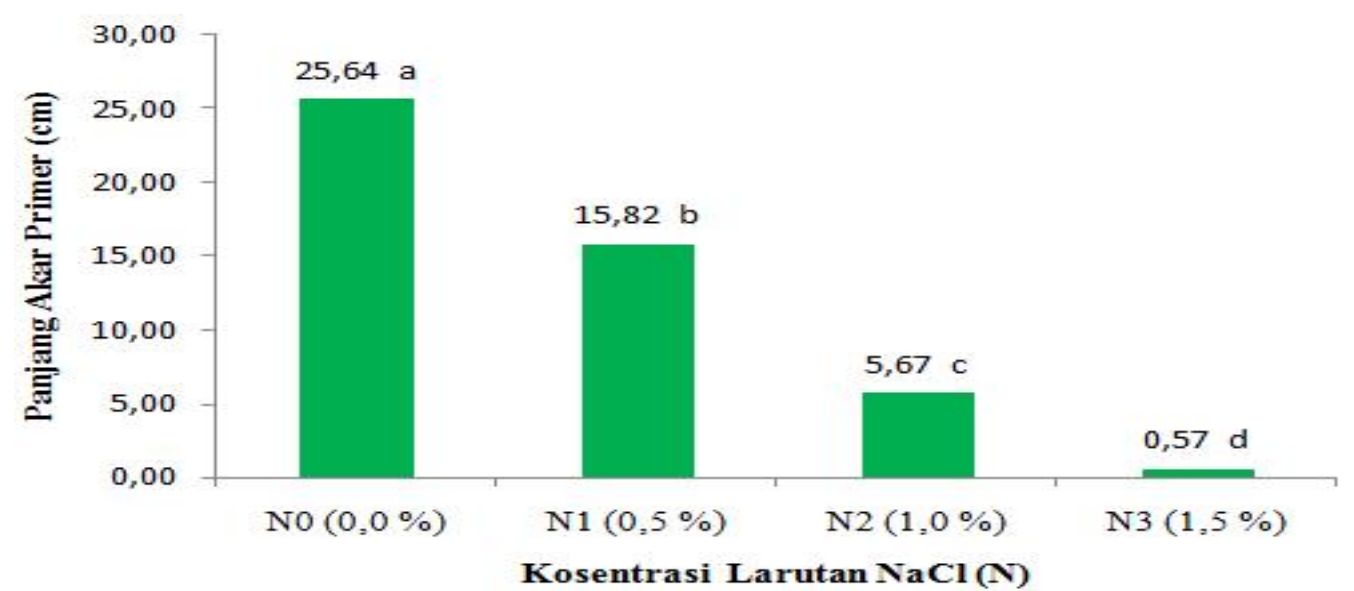

Gambar 7. Panjang akar primer benih kedelai akibat perlakuan konsentrasi larutan $\mathrm{NaCl}$ (cm); Angka yang diikuti oleh huruf yang sama menunjukkan tidak berbeda nyata berdasarkan uji Duncan taraf $5 \%$; Data panjang akar primer ditransformasi dengan Arcsin $\sqrt{ }(x+0,5)$. 
Kosentrasi $\mathrm{NaCl}$ mempengaruhi panjang hipokotil benih kedelai. Semakin tinggi kosentrasi $\mathrm{NaCl}$, pertumbuhan hipokotil benih kedelai juga semakin $\begin{array}{llll}\text { menurun. Kosentrasi } & \mathrm{NaCl} & 1,0 & \%\end{array}$ menghasilkan pertumbuhan hipokotil paling rendah sebesar $6,08 \mathrm{~cm}$. Perlakuan kosentrasi $\mathrm{NaCl}$ juga menyebakan penurunan panjang akar primer benih kedelai, Kosentrasi $\mathrm{NaCl} \quad 1,0 \quad \%$ menghasilkan panjang akar primer paling rendah sebesar $5,67 \mathrm{~cm}$, sedangkan pada kosentrasi $1,5 \%$ benih sudah tidak mampu untuk berkecambah (Gambar 6 dan 7).

Pengaruh $\mathrm{NaCl}$ pada proses perkecambahan antara lain mengurangi hidrasi dari embrio dan kotiledon, menghambat dan mengurangi pemunculan radikula dan plumula, serta mengurangi pertumbuhan kecambah (Erinovita et al., 2008). Peningkatan konsentrasi $\mathrm{NaCl}$ dapat menghambat proses imbibisi benih karena kelarutan garam dapat menurunan tekanan osmotik sehingga benih tidak dapat menyerap air dari lingkungan tumbuhnya yang diperlukan untuk pengaktifan enzim guna proses perkecambahan. Rini et al. (2005) menyatakan bahwa salinitas pada media tanam benih dapat mempengaruhi proses perkecambahan benih karena dapat menurunkan potensial air pada media tanam sehingga menghambat penyerapan air oleh benih yang berkecambah. sehingga pertumbuhan hipokotil mengalami hambatan.

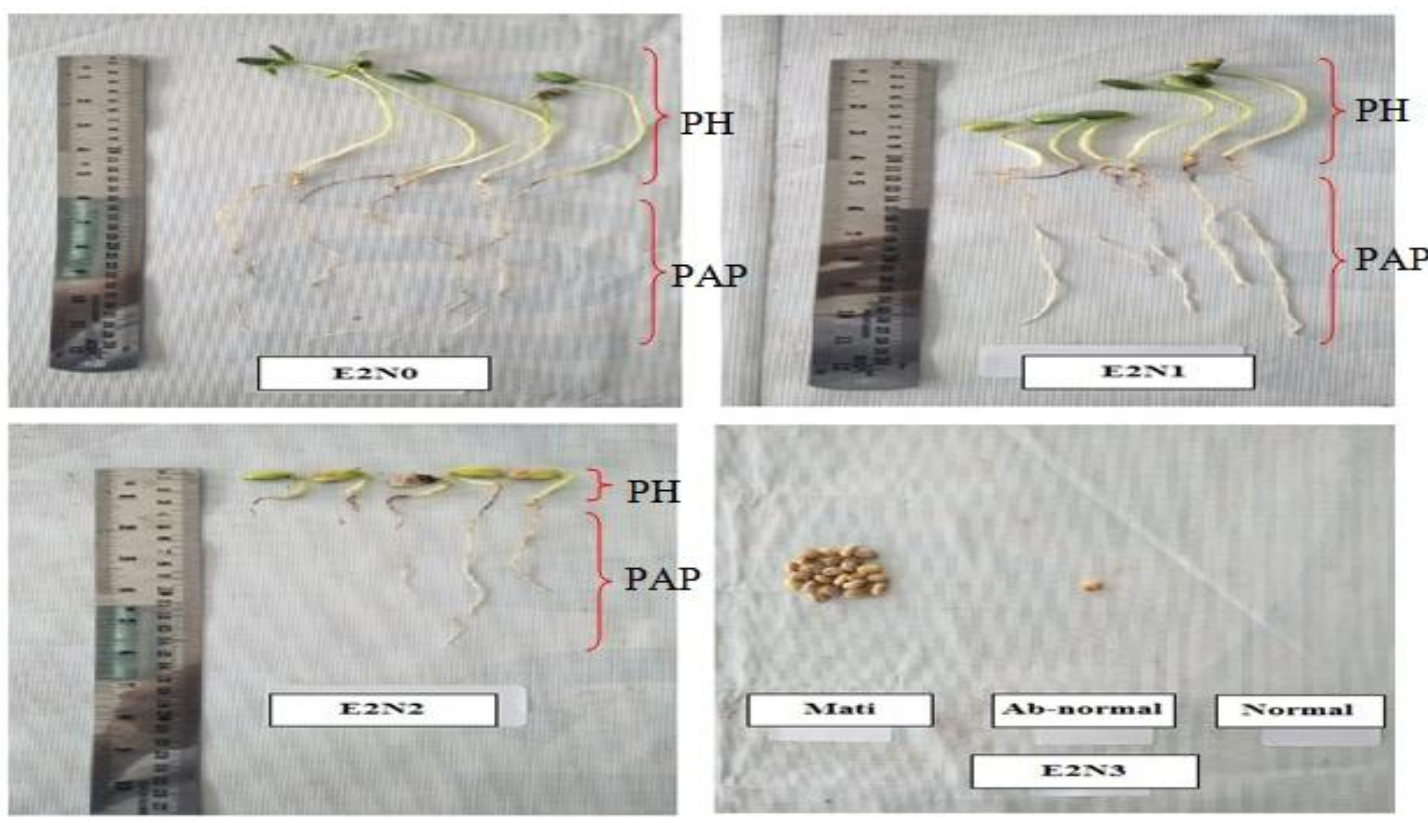

Gambar 8. Perbandingan performansi panjang hipokotil $(\mathrm{PH})$ dan panjang akar primer (PAP) benih kedelai (Glycine max (L.) Merrill) akibat perlakuan larutan $\mathrm{NaCl}$ kosentrasi $0,0 \%(\mathrm{~N} 0), 0,5 \%(\mathrm{~N} 1), 1,0 \%(\mathrm{~N} 2)$ dan 1,5\% (N3).

Adanya cekaman salinitas yang tinggi diduga menyebabkan berkurangnya pembelahan sel-sel pada akar. Potensial osmotik media tumbuh yang lebih rendah dibandingkan dengan potensial osmotik didalam sel, dapat menghambat pembelahan sel-sel akar (Yuniati, 2004).
Selanjutnya menurut Fitter and Hay (1994), salah satu pengaruh negatif garam pada tanaman dapat berupa berkurangnya kemampuan tanaman dalam menyerap air sehingga berpengaruh terhadap proses pembelahan sel dan mempengaruhi fungsi hormon. Cekaman garam yang berlebih 
dapat menurunkan fungsi hormon auksin (Pessarakli, 1993). Auksin berperan dalam memacu pembelahan dan pembesaran sel akar (Gardner et al., 1991).

Bedasarkan nilai rata-rata parameter panjang hipokotil dan panjang akar primer benih kedelai pada perlakuan kosentrasi larutan $\mathrm{NaCl}$ dapat dilihat bahwa pertumbuhan panjang akar primer lebih tinggi dibandingkan dengan pertumbuhan panjang hipokotil pada perlakuan kosentrasi larutan $\mathrm{NaCl}$ (Gambar 6 dan 7). Dengan kata lain, meningkatnya cekaman salinitas menyebabkan pertumbuhan ke bagian atas cenderung lebih tertekan dibandingkan dengan pertumbuhan ke bagian bawah. Kondisi ini sejalan dengan hasil penelitian Hassen et al., (2014) bahwa pertumbuhan plumula lebih tertekan dibandingkan radikula. Hal ini dapat terjadi sebagai akibat dari penyesuaian osmotik yang cepat terhadap cekaman salinitas, sebagai salah satu mekanisme toleransi tanaman terhadap cekaman salinitas (Roy et al., 2014).

\section{KESIMPULAN}

Pemberian ekstrak telur keong mas kosentrasi $45 \%$ hanya dapat meningkatkan daya berkecambah sebesar 51,59\%, kecepatan tumbuh sebesar 24,18\%/etmal dan vigor kecambah sebesar $33,55 \%$ pada kondisi cekaman salinitas hingga 0,5\%, namun pada cekaman salinitas $1,0 \%$ dan $1,5 \%$ benih sudah tidak mampu untuk berkecambah normal.

Hubungan tingkat salinitas dengan ketahanan benih kedelai pada perlakuan perendaman ekstrak telur keong mas $45 \%$ berbentuk linier negatif yaitu semakin tinggi kosentrasi $\mathrm{NaCl}$ (salinitas) maka semakin menurun viabilitanya dengan $\mathrm{R}^{2}=$ 0,870 pada daya berkecambah, $\mathrm{R}^{2}=0,862$ pada kecepatan tumbuh dan $\mathrm{R}^{2}=0,880$ pada vigor kecambah.

Peningkatan cekaman salinitas 0\%-1,0\% menyebabkan pengurangan panjang hipokotil dan panjang akar primer benih kedelai. Pemberian ekstrak telur keong mas kosentrasi $45 \%$ menghasilkan hipokotil dan akar primer benih kedelai yang lebih panjang dibandingkan dengan tanpa pemberian ekstrak, terjadi peningkatan panjang hipokotil sebesar 14,53\% dan panjang akar primer sebesar $16,25 \%$ akibat pemberian ekstrak telur keong mas.

Hasil penelitian membuktikan adanya perbaikan viabilitas dan vigoritas benih yang ditunjukkan oleh indikasi fisiologi yaitu perbaikan performansi panjang hipokotil dan akar primer, meningkatkan nilai kecepatan tumbuh dan vigor kecambah benih kedelai dengan perendaman ekstrak telur keong mas pada kondisi salinitas walaupun pada level yang rendah.

\section{DAFTAR PUSTAKA}

Addai, I. K., and O. S. Kantanka. 2006. Evaluation of screening methods for improved storability of soybean seed. Int. J. Bot. 2: 152155.

Dreon MS, Heras H, Pollero RJ. 2004. Biochemical composition, tissue origin and functional properties of egg perivitellins from Pomacea canaliculata. Biocell 30(2): 359365 .

Grattan, S. R. 2005. Irrigation water salinityand crop production. ANR Publication 8066. University of California Agriculture and Natural Resources in partnership with Natural Resources Conservation Service. 
Hassen, A., Maher, S., and Cherif, H. 2014. Effect of Salt Stress on Germination and Early Seedling Parameters of three Pepper Cultivars (Capsicum annuum L). Journal of Stress Physiology and Biochemistry 10 (1): 15-25.

Kurashige, M., Okimasu, E., Inoue, M. and Utsumi, K. 1990. Inhibition of Oxidative Injury of Biological Membranes by Astaxanthin. Physiol. Chem. Pys. \& Med. 22: 27-38.

Pritchard, S. G., Ju, Z., Santen, E. V., Qiu, J., Weaver, D. B., Prior, S. A. And Roger, H. 2000. The influence of elevanted $\mathrm{CO}_{2}$ on the activities of antioxidative enzymes in two soybean genotypes. Aust J Plant Physiol 27:1061-1068.

Prochazkova, D., Sairam, R. K., Srivastava, G. C., Singh, D. V. 2001. Oxidative stress and antioxidant activity as the basis of senescence in maize leaves. Plant Science 161: 765-771.

Roy, S. J., Negro, S, and Tester, M. 2014. Salt Resistant Crop Plants. Current Opinion in Biotechnology 26: 115-124.

Shiddiqui, S. U., Ali, A., and Chaudhary, A. M. 2008. Germination behavior of wheat (Triticum aestivum) varieties to artificial ageing under varying temperature and humidity. Pak. J. Bot. 40:1121-1127.

Soltani, A., Mohammadi, H., Sadeghipour, H. R., and Zaenali, E. 2010. Effect of seed aging on subsequent seed reserve utilization and seedling growth in soybean. Int. J. Plant Prod. 5:1735-6814.
Stahl, W. and Sies, H. 2003. Antioxidant Activity of Carotenoids. Molecular Asfects of Medicine. 24, 345-351.

Suwarno dan Solahudin, S. 1983. Toleransi varietas padi terhadap salinitas pada fase perkecambahan. Bul. Agron. XIV (3) : 1-1.

Wahid, A., E. Rasul, and A. R. Rao. 1999. Germination of seeds and propagules under salinity stress, page 153-167. In: M. Pessarakli (Ed.). Handbook of Plant and Crop Stress. 2nd ed. Marcel Dekker Inc. New York. USA. $627 \mathrm{p}$. 